\title{
The Surface of the Plasmodium falciparum-infected Erythrocyte
}

\author{
Joseph D. Smith ${ }^{1,2}$ and Alister G. Craig ${ }^{3, *}$ \\ ${ }^{1}$ Department of Pathology, Colorado State University, Ft. \\ Collins, CO 80523-1671, USA \\ ${ }^{2}$ Present address: Seattle Biomedical Institute, \\ Four Nickerson Street, Suite 200, Seattle, \\ WA 98109-1651, USA \\ ${ }^{3}$ Liverpool School of Tropical Medicine, Pembroke Place, \\ Liverpool L3 5QA, UK
}

\begin{abstract}
In order to navigate its complex lifecycle, the malaria parasites must interact with a range of host cells. Examples of this are the invasion of hepatocytes by sporozoites and erythrocyte invasion by merozoites. This requirement for cell recognition brings with it the need to display cognate ligands on the parasite surface, and therefore the capacity of the host to develop defences against the infection. Even at a stage where the intracellular nature of erythrocyte development would appear to offer an opportunity for the parasite to be immunologically "silent", parasite-derived proteins are found on the surface of the infected erythrocyte. This review will discuss the proteins found on or associated with the surface of the infected erythrocyte and the resulting phenotypes.
\end{abstract}

\section{Modifications Occurring to the Surface of Infected Erythrocytes}

Plasmodium parasites have a complex life cycle that includes multiple stages of development both within a vertebrate and an anopheles mosquito host (for a recent review see Waters and Janse, 2004). Although Plasmodium are capable of establishing chronic infections in humans that can last as long as a year, survival of the parasite species is ultimately conditioned upon effective transmission between hosts. Indeed, the cycle of transmission requires a sexual replication cycle that is initiated in the vertebrate host but can only be completed in the mosquito. Thus, while malaria parasites replicate asexually in vertebrates to increase numbers and presumably enhance transmission success, they have evolved sophisticated mechanisms to ensure their transmission back to the mosquito. This review focuses on alterations occurring at the surface of infected erythrocytes with a special emphasis on $P$. falciparum, the most important Plasmodium species that infects humans. Reference is made to parallel mechanisms operating throughout the Plasmodium genus.

The initial period of parasite development in humans begins in the liver and last for approximately 7 to 10 days. This stage is not associated with disease but is an important period of growth and amplification that allows

*For correspondence. Email agcraig@liverpool.ac.uk. the parasite to overcome a transmission bottleneck due to the fact that few parasites are inoculated when a mosquito bites. While only a single parasite may infect a hepatocyte, 20-40,000 parasites are released at the end of the liver stage to infect erythrocytes.

The erythrocytic stage of parasite development produces a chronic infection that can last for over a year and during which disease can occur. In erythrocytes, $P$. falciparum grows, differentiates, and divides in a compartment within the erythrocyte cytoplasm called the parasitophorous vacuole. Asexual division of $P$. falciparum requires approximately 48 hrs. For each parasite that infects an erythrocyte approximately 10 to 24 are released to infect new red blood cells leading to amplification of the infection. Importantly, the number of infected erythrocytes (IE) is a significant risk factor for disease so that an important component of host immunity is directed at limiting parasite growth. Also within erythrocytes some parasites differentiate to sexual forms in a process that is still not completely understood. These gametocyte-infected erythrocytes are infective for mosquitoes and are responsible for completing the cycle of transmission the next time a mosquito feeds.

$P$. falciparum-infected erythrocytes display several dramatic morphological changes that affect membrane rigidity, surface antigenic character, and permeability. These changes are intimately connected to Plasmodium biology and involved in nutrient acquisition, the establishment of chronic infections, and the evolution of new adhesive properties displayed by some Plasmodium species. Parasite-induced modifications occur both to the erythrocyte cytoskeleton and the extracellular face of the membrane. Although sub-cellular modifications are critical to new adhesive properties exhibited by $P$. falciparum-infected erythrocytes these will only be briefly described here (for a review see Cooke et al., 2001). Rather, the major focus of this review will be parasite proteins demonstrated or proposed to be surfaceexposed on asexually-parasitised erythrocytes. Several excellent reviews on parasite proteins exported to the erythrocyte cytoskeleton have recently been written.

Until relatively recently the infected erythrocyte surface was regarded as having very few parasitederived proteins on it. The earliest candidates were a modification of an existing erythrocyte protein, band 3 (Winograd and Sherman, 1989), and a biochemically defined, surface-labellable variant protein known as $P$. falciparum erythrocyte membrane protein 1 (PfEMP1) (Leech et al., 1984). A combination of further biochemical characterisation and the advent of the genome sequence has provided a range of new IE surface candidates, turning a rather sparse molecular "landscape" into a potentially complex interface between parasite and host.

Before describing these different proteins and the evidence placing them at the erythrocyte surface it is constructive to briefly review our understanding of the 
natural immune response to $P$. falciparum infection and resulting expectations for surface-exposed parasite proteins. Protective immunity to $P$. falciparum is acquired slowly and only after repeated infections. The immunity that develops does not appear to ever provide complete protection from infection but does protect against disease and is still imprecisely understood. However, there is increasing evidence that natural malaria immunity is comprised of different elements including anti-disease and anti-parasite components that evolve with characteristic and distinct kinetics. In addition, there is evidence for clonal antigenic variation of antigens at the surface of infected erythrocytes that may allow parasites to establish chronic infections (for a review see Bull and Marsh, 2002). The variant antigens are highly immunodominant and antibodies that develop to them are typically strainspecific but appear to have a protective role against infection. Given the slow evolution of malaria immunity the parasite is highly successful at evading immunity. Strategies that a parasite might use to avoid immunity to surface-exposed proteins are to have these proteins belonging to large, diverse and varying protein families so that it takes an individual a long time to learn the different variants. Alternatively, parasite surface proteins may be exposed for only limited times or relatively inaccessible to antibody. Using these criteria we will review the list of potential surface-exposed parasite proteins beginning with the best-characterised example, PfEMP1.

\section{PfEMP1}

Evidence for the presence of neo-antigens on the IE surface was first suggested by Brown and Brown (Brown and Brown, 1965) in their seminal paper on antigenic variation in the primate malaria Plasmodium knowlesi. In the mid-1980's more direct molecular evidence was produced in two laboratories using radio-iodination of infected erythrocytes from primate $(P$. knowlesi; Howard et al., 1983) and human (P. falciparum; Leech et al., 1984) malarias. The latter identified a protein of variable molecular weight (200-350kDa) between different parasite lines that was Triton X-100 insoluble and sensitive to protease digestion of intact IE. Subsequent studies have demonstrated that this protease sensitivity is not universal (Chaiyaroj et al., 1994; Gardner et al., 1996) but this initial result supported the presence of this protein on the erythrocyte surface. This protein, termed Plasmodium falciparum erythrocyte membrane protein 1 (PfEMP1), became the target for intense study over the next ten years but proved difficult to work with due to relatively low abundance and the paucity of specific immunological reagents. As often seen in science, the breakthrough, when it came, derived from the work of several groups in identifying the gene family encoding PfEMP1, namely the var genes (Baruch et al., 1995; Smith et al., 1995; Su et al., 1995). The basis for this discovery came from several sources but mainly the production of a monoclonal antibody specific for a single PfEMP1, the identification of a candidate gene from a sequencing study (looking for the chloroquine-resitance gene!), the production of a phenotypically characterised parasite clone tree, and the development of antibodies to recombinant protein fragments of the genes.
The structure of the var gene matched the scientific expectations very well, with it being a multi-gene family with $50-60$ copies per haploid genome and having a high degree of sequence divergence between different family members. This could not only explain the ability of parasites to switch antigenically, through differential expression of var genes, but also why sera from people infected by $P$. falciparum only agglutinated IEs from samples taken from earlier waves of parasitemia and not those from later peaks ((Brown and Brown, 1965; Hommel et al., 1983)). By having a repertoire of surface-expressed PfEMP1s with little similarity and a mechanism of mutually exclusive gene expression, the parasite would be able to switch from one antigenic type to another in the face of host immune pressure. This form of immune evasion is believed to be an important factor in the establishment of chronic infection and presumably enhances transmission. Moreover, not only is the var repertoire of a single parasite genotype highly diverse but there is extensive diversity of var genes between different parasite genotypes. Estimates of var diversity based upon degenerate primers have demonstrated that there is little similarity in repertoires between different parasite genotypes (Fowler et al., 2002; Kyes et al., 1997). Thus, at the population level there is an incredible variety of sequence that may only be limited by the functional requirement of the protein to cytoadhere (see below). Strain-specific variation between var repertoires might explain why convalescent sera from children infected by $P$. falciparum agglutinate homologous parasites but frequently show little or no reactivity with heterologous parasites (Bull et al., 1998).

Unlike many clonally variant antigens that appear to act only as immunological "smokescreens" or for which other functions have not yet been defined, PfEMP1 also encode binding properties. Around sixteen hours after merozoite invasion IE are able to adhere to a number of host receptors. In people suffering from malaria this can be seen as a sequestering of the parasites from the peripheral circulation into a number of microvascular sites around the body. Sequestration of infected erythrocytes has been recognised as a characteristic trait of $P$. falciparum infection for over 100 years and is a major pathogenic feature of disease. Perhaps the most famous example of how sequestration causes disease is cerebral malaria, which is associated with parasite adhesion to brain microvasculature and carries with it a high case-fatality (MacPherson et al., 1985). However, sequestration appears to have an equally important role in pathogenesis that occurs in pregnant women (Fried and Duffy, 1996) and might impact malaria pathogenesis in multiple ways through other parasite-host cellular interactions discussed in the following sections.

PfEMP1 are key mediators in binding interactions between infected erythrocytes and host cells. While infected erythrocytes display a range of different binding properties (for reviews see (Cooke et al., 2001; Craig and Scherf, 2001; Kyes et al., 2001), individual parasites differ in their receptor specificity depending upon the expressed PfEMP1. An important question that is being addressed is how parasite receptor specificity influences parasite tropism for different tissues and cells and the impact on 


\section{Sub-telomeric repeats}

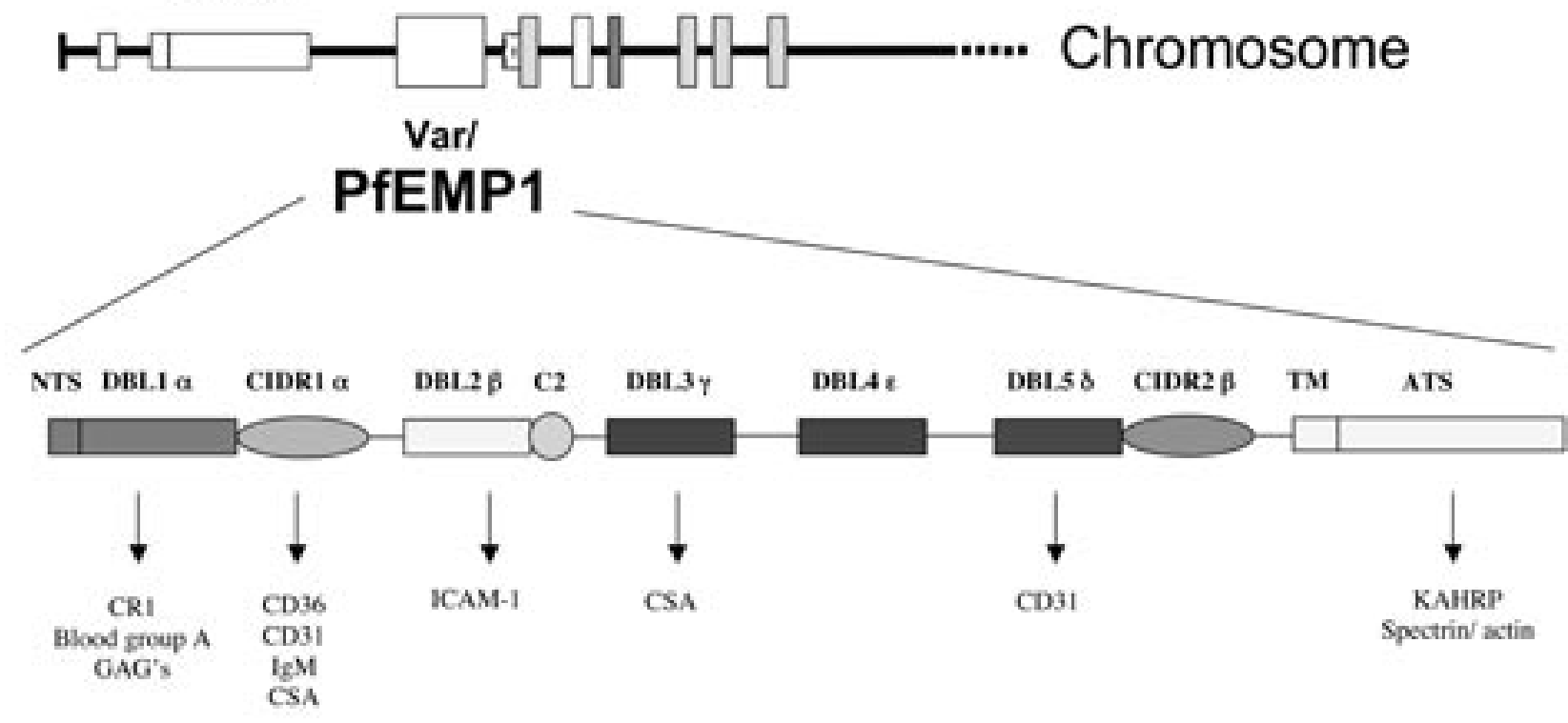

Figure 1. Schematic showing the general organisation of the sub-telomeric region of P.falciparum chromosomes (Bowman et al., 1999; Gardner et al., 1998) and structure of PfEMP1. At the top, left-hand side of the figure chromosomal elements are indicated for a telomeric repeat sequence followed by sub-telomeric repetitive elements (R-CG7, rep11, and rep20, respectively). Repetitive elements are followed by a var gene, R-FA3 repeat sequence and rif/ stevor genes. Regions of PfEMP1 are indicated in the text except the transmembrane region (TM) and acidic terminal segment (ATS). The nomenclature for motifs within PfEMP1 indicates the position in the molecule (1-5) and the sequence type $(\alpha-\varepsilon)$. Note that the sequence types can be in different orders, except for DBL $1 \alpha$, which is always the N-terminal domain. The receptors for the various regions of PfEMP1 are indicated below the schematic.

disease. To begin to understand PfEMP1 function binding assays have been developed to examine recombinant proteins from these genes and sequence analyses have been performed (Smith et al., 2000a; 2001; 2000b).

var genes are encoded in two exons. The first exon codes for the variable extracellular binding region and a transmembrane domain, while the second exon encodes a more conserved cytoplasmic tail. The PfEMP1 binding region is comprised of four different domains. These domains are the N-terminal segment (NTS), Duffybinding-like (DBL) domain, the cysteine-rich interdomain region (CIDR), and the $\mathrm{C} 2$ domain. Both the $\mathrm{DBL}$ and CIDR domains have been demonstrated to possess adhesive properties and a system of adhesive domain classification has been developed to define their sequence relatedness. From a study of 20 different PfEMP1(Smith et al., 2001), DBL domains grouped into five different sequence types: $\alpha, \beta, \gamma, \delta$, and $\varepsilon$. In contrast, CIDR domains grouped into three types: $\alpha, \beta$, and $\gamma$. Within each adhesive domain classification there are a variety of different sequences, however, domains of a type share characteristic and distinctive amino acid features. As the number, location, and type of DBL and CIDR domains vary between PfEMP1 proteins, a nomenclature has been introduced that describes both the numeric position and sequence type of the domain (Figure 1).

Although PfEMP1 proteins are variably sized, an important concept that has emerged from sequence analysis is that the binding region is not created through a random assortment of domains. Rather adhesive domain sequence types tend to occupy characteristic positions in the protein and associate in favoured tandems. For instance, one tandem association is the DBL $\alpha$ and CIDR domains that form the semi-conserved head structure of almost all PfEMP1 (Chen et al., 2000; Su et al., 1995)(Figure 1). Other tandem combinations, DBL $\beta-C 2$ and DBL $\delta$-CIDR are found internal to the head structure. Thus, adhesive domain sequence classification provides insight into PfEMP1 protein architecture and may have implications for binding function. At present, only limited numbers of PfEMP1 adhesive domains have been functionally characterised but already there are multiple examples in which different parasites adhesion traits have been shown to map to the same adhesive domain type. For instance, two different CSA-binding parasites used a DBL $\gamma$ type domain to bind CSA even though the $\mathrm{DBL} \gamma$ sequences were distinct. One hypothesis that is being tested is the extent to which different PfEMP1 proteins that bind the same receptor use the same adhesive domain sequence type to bind. If there were functional constraints that caused like-binding domains to have a related structure and antigenicity this could have implications for vaccine design (Duffy et al., 2001). Investigations have already begun to test for crossreactive epitopes in different PfEMP1 domains (Gamain et al., 2001). Our understanding of malaria pathogenesis 
will also likely improve with further investigation of PfEMP1 function. For instance, small and large PfEMP1 have quite distinctive protein architectures and are comprised of different adhesive domain types. Large PfEMP1 may possess special adhesive characteristics responsible for a distinct spectrum of sequestration and disease outcomes.

From the beginning studies that established a surface localisation for PfEMP1 proteins using iodination and trypsin sensitivity to the development of serological reagents and functional assays, there are now multiple lines of evidence confirming PfEMP1s surface expression.

\section{Rifins}

The Rifins are comprised of two related but slightly distinctive multiple gene families, the rifs and the stevors, discussed separately below.

\section{Rifs}

Rifs were originally identified as a repetitive gene sequence (rif), which could be used to characterise different parasite lines due to the highly variable banding pattern seen on southern blots of genomic DNA from different lines of $P$. falciparum when probed with this sequence (Weber, 1988). The possibility that rifs encoded a set of surface proteins that were initially linked with rosetting (termed rosettins (Helmby et al., 1993)), and subsequently with binding to CD31 (Fernandez et al., 1999) was not recognised until the advent of the $P$. falciparum genome project (Gardner et al., 1998). Sequences with similarity to the original rif gene were found as tandem arrays within the sub-telomeric regions. Initially it was not clear that they were expressed as they appeared to lack a proper $5^{\prime}$ region, but careful inspection of the DNA sequence revealed a small 5 ' exon. It now appears that rif genes have a two-exon structure, with the first exon coding for a predicted signal peptide and the second for a protein that is highly variable but contain stretches of relative amino acid conservation and conserved cysteine residues. The actual orientation of Rif proteins within the membrane is still debated because the second exon codes for more than one block of hydrophobic residues that could potentially act as a transmembrane domain. Thus, it is not known whether the bulk of the protein is exposed or whether Rif proteins make multiple passes through the membrane. However, most models predict that Rif proteins have at least one transmembrane domain near the end of the protein that is followed by a short, highly conserved cytoplasmic tail. Members of the rif gene constitute the largest gene family in $P$. falciparum discovered so far, with in excess of two hundred copies per genome.

The physical proximity of rif genes to var genes raised some early speculation that both gene families might be regulated in a co-ordinated fashion, but evidence to support this scenario remains to be established. A transcriptional analysis of var and rif expression indicated that var messages were expressed relatively early after erythrocyte invasion with a peak around $12 \mathrm{~h}$ post-invasion while rif messages were limited to late ring and early trophozoite stages (Kyes et al., 2000). Despite transcriptional differences, evidence has been presented that Rifs are co-expressed on the infected erythrocyte surface with PfEMP1 (Fernandez et al., 1999; Kyes et al., 1999). This evidence consists of similar criteria that were originally developed to establish the surface expression of PfEMP1. Thus, it has been demonstrated that Rif proteins are iodinatable and trypsin-sensitive albeit with a much higher trypsin requirement than PfEMP1. Unlike PfEMP1, there is no published evidence that antibodies raised to Rif recombinant proteins react with the infected erythrocyte surface although hyperimmune sera from adults in malaria endemic regions are able to immunoprecipitate the proteins indicating their natural immunogenecity (Fernandez et al., 1999). It is curious that Rif proteins are predicted to act as clonal variant antigens, yet it has been difficult to establish their surface expression with antibodies. Equally elusive is the function of Rif proteins despite attempts to link their expression with specific adhesive phenotypes. However, the investment by $P$. falciparum in maintaining a large repertoire of these genes and the differential expression of rifs by parasite lines would indicate that they play an important role in the interaction between parasite and human host.

\section{Stevor}

Stevor genes are also found in close proximity to var and rif genes. Like rif, Stevor began as a multicopy probe for distinguishing $P$. falciparum isolates (Limpaiboon et al., 1991) but was later recognized to have a two-exon gene structure in which the first exon is predicted to code for a signal peptide and the second for the protein (Cheng et al., 1998). Within the protein, Rif and Stevor share some conserved cysteines and align with each other by Blast analysis but the two protein families have characteristic and distinct features including different numbers of conserved cysteines (Cheng et al., 1998). Although the cytoplasmic domain of Stevors is relatively well conserved between different proteins it is distinct from that of Rif proteins. Like rif, stevor probes generate multiple bands on P. falciparum genomic DNA. However, unlike rif there is no published data indicating expression on the IE surface, although unpublished data suggest that stevor are transcribed in sexual and asexual stages and localised in the Maurer's clefts in the latter. Since no clear functions have been described for either rif or stevor gene products it is uncertain whether these protein families have similar or distinct activities.

\section{KAHRP and CLAG9}

Upon adaptation of $P$. falciparum to in vitro cultivation, many parasite cultures gradually lose the capacity to cytoadhere over a period of weeks (Udeinya et al., 1983). Chromosomal deletions are frequently observed in $P$. falciparum, particularly during in vitro propagation. These genetic deletions are often associated with chromosome ends and can extend for as much as $500 \mathrm{~kb}$. While the deletion events appear to offer an in vitro growth advantage to the parasite outside of the context of a human host, non-cytoadherent parasite strains have proven a valuable resource to investigate the molecular requirements for infected erythrocyte cytoadherence. 
The first chromosomal deletion to be characterised in molecular detail occurred in a telomere end of chromosome 2 and resulted in the loss of a protein called the knob-associated histidine-rich protein (KAHRP) (Pologe and Ravetch, 1986). KAHRP is transported by the parasite out of the parsitophorous vacuole and forms an association with the erythrocyte membrane cytoskeleton (Kilejian et al., 1991; Waller et al., 1999). This association leads to the production of knob-like membrane protuberances at the erythrocyte surface that are the point of contact between infected erythrocytes and endothelium. Although KAHRP is completely intracellular and not a parasite adhesion receptor it has been shown to be essential for knob formation and the binding of infected erythrocytes under conditions of flow (Crabb et al., 1997).

Another common deletion in laboratory-adapted parasite isolates occurs on chromosome 9 (Barnes et al., 1994; Day et al., 1993; Shirley et al., 1990). This deletion has been linked with the loss of cytoadherence to C32 melanoma cells (Barnes et al., 1994), but not all cytoadherence (Chaiyaroj et al., 1994). Initially it was thought that a gene encoding PfEMP1 might map within this region but subsequent detailed analysis of the locus showed that parasites with smaller deletions but still showing the loss of adherence retained the var gene at the end of chromosome 9 (Holt et al., 1998). Sequencing of the deleted region revealed a complex structure consisting of nine exons, producing a mature transcript of around $7 \mathrm{~kb}$. This gene was called cytoadherencelinked asexual gene (clag9) (Trenholme et al., 2000) and encodes a protein of about $220 \mathrm{kDa}$ that is associated with the IE membrane, but has not been proven to be on the surface. A number of transfection-based experiments have indicated that this gene is essential for adhesion to C32 via CD36, such that clag9 knockout or antisense parasites lose the ability to bind to these cells (Gardiner et al., 2000; Trenholme et al., 2000). However it is not clear at what stage in the adhesion process clag 9 acts and it is possible that the gene product is involved in the translocation of PfEMP1 from the cytoplasm to the IE surface, rather than being directly involved in adhesion.

It is perhaps surprising given the loss of phenotype seen in the clag9 knockout that there are several clag genes in the $P$. falciparum genome. The genomesequencing project has revealed at least five related sequences (Holt et al., 1999), located close to the varl rif/stevor clusters at the end of the chromosomes. One of these, on chromosome 3, has been identified recently as encoding $\mathrm{RhopH} 1$, one of three proteins that make up the RhopH complex in the rhopteries of the malarial merozoite (Kaneko et al., 2001). Further evidence for the involvement of clag paralogues in merozoite function has come from the discovery of two clag-related sequences in the rodent malaria P.yoelii (pyrhoph1a and pyrhoph1a$p)$. It appears that this family of sequences, now termed rhoph1/clag, mediate broader cell-cell interactions that was previously thought and it will be interesting to see at a structural level how Plasmodium has used this gene framework to address cell adhesion in multiple contexts.

\section{Others}

A number of other potential parasite ligands on the IE surface have been described as well as permeation pathway involving a voltage-dependent channel which allows the parasite to acquire the metabolites it needs to develop in what is essentially a metabolically inactive cell.

\section{Band 3}

The best characterised of this group of molecules is in fact a host protein that is modified by the parasite. Band 3 is a highly abundant erythrocyte surface protein that acts as an anion transporter. Modification of this protein is involved in the clearance of senescent erythrocytes, through the exposure of cryptic epitopes. Invasion by $P$. falciparum also causes modification to Band 3 , which can be recognised by specific monoclonal antibodies (Crandall and Sherman, 1991). The basis of the modification is unknown but early experiments suggested that modified Band 3 was involved in adhesion to a range of cells via CD36. However, more recent data have implicated thrombospondin as the receptor (Eda et al., 1999).

\section{Sequestrin}

Another potential parasite adhesion receptor is called Sequestrin (Ockenhouse et al., 1991). Sequestrin was identified using anti-idiotype antibodies to an anti-CD36 monoclonal antibody that could block infected erythrocyte cytoadherence. The sera precipitated an approximately $270 \mathrm{kDa}$ surface-iodinatable protein. Unpublished observations have described a gene for the Sequestrin protein but some doubts on the function of this protein are raised by a lack of an effect on cytoadherence in genetic knockout experiments (Trenholme et al., 2000).

\section{RSP1 and RSP2}

One recent surprising result was the description of a new form of cytoadherence involving immature ring-stage forms of infected erythrocytes. It has been a long accepted dogma that immature forms of parasites circulate in the blood until approximately $16 \mathrm{hrs}$ post-invasion when sequestration begins for more mature parasite forms. The new work investigating the stage-specific regulation of cytoadherence focused on mature parasites that had been selected to bind CSA but were simultaneously selected to express distinct adhesion ligands at the immature parasite stage. The fascinating observation was the ring-infected erythrocytes of parasites selected to bind CSA were able to adhere to some types of cultured endothelium and placenta tissue sections, but not via CSA (Pouvelle et al., 2000). The binding appears to be mediated by two parasite-encoded proteins, RSP1 and 2, that are expressed on the erythrocyte surface shortly after parasite invasion. Adhesion of immature parasite forms appears to be mechanistically distinct from mature parasites since it occurs independently of knobs. In addition, there are still unanswered questions about the relationship of this binding phenotype to particular parasite adhesion traits. However, these results suggest that there may be non-circulating (cryptic) ringinfected erythrocyte subpopulations in malaria patients. Interestingly, a recent study by (Silamut et al., 1999) was 
the first to describe a cryptic population of ring-infected erythrocytes in the brain microvasculature of individuals who died from cerebral malaria.

"New Permeation Pathway" (NPP)

Other surface changes reflect nutritional requirements of the growing intraerythrocytic parasite. Erythrocytes are an interesting cell to parasitise because they are nearly metabolically inert and have been commonly referred to as "bags of haemoglobin". Despite their metabolic limitations, another protozoan parasite, Babesia, also invades and develops within erythrocytes during a period of its life cycle. During their development, Plasmodium parasites sample the contents of the erythrocyte cytoplasm and use haemoglobin as an important nutritional source. Although many of the amino acids required for parasite growth are supplied from haemoglobin metabolism, parasitised erythrocytes also acquire enhanced permeability characteristics that allow the uptake of factors from blood serum. This so-called "New Permeation Pathway" (NPP) (Desai et al., 2000) is indicated by the increased uptake of many solutes including anions, sugars, purines, amino acids and organic cations and has been measured experimentally using a whole-cell voltage-clamp method on infected erythrocytes. Identifying the voltage-gated channel is a subject of intense molecular investigation, but it is not yet demonstrated whether it is caused by the insertion of parasite protein(s) in the erythrocyte membrane or modification of host red cell proteins.

\section{Phenotypes Associated With the IE Surface}

From the description above it can be seen that the major roles for the proteins on the surface of the IE are antigenic variation and adhesion. While all Plasmodium species that have been studied to date possess a capacity to vary surface antigenic character, it is not clear why an ability to cytoadhere has only developed for $P$. falciparum among the human malarias. However, this property appears a key determinant in the enhanced virulence of this species.

\section{Clonal Antigenic Variation}

At first glance it may appear curious that a parasite living within a erythrocyte, a cell that is relatively inaccessible to cellular immunity because it does not present peptide antigens through either the class I or class II antigenpresenting systems, would expose itself to antibody by exporting proteins to the erythrocyte surface. However, it has been pointed out that clonal antigenic variation is a common theme of different pathogens that rely on insect vectors to complete their life cycle (Kyes et al., 2001). Clonal antigenic variation is probably an important factor that allows parasites to establish chronic infections and ensure transmission during periods when host to host contact is sporadic (e.g. during the dry season for malaria parasites). The importance of clonal antigenic variation to Plasmodium biology is demonstrated by the fact that it exists throughout the genus. Recently, several different large and diverse protein families expressed during the erythrocytic period of development have been described from several Plasmodium species. Although direct evidence for surface variant exposure of these proteins is still being established for all but $P$. falciparum, it is interesting that only some of these protein families are common while some species like $P$. falciparum appear to have evolved distinct and unique protein families. To date, no sequences sharing significant similarity to var or rifin genes have been reported from other Plasmodium species even though some, like $P$. falciparum, cytoadhere. It will be interesting to test for var and rifin genes in $P$. falciparum's nearest evolutionary relatives. However, a gene coding for the variant surface antigen of $P$. knowlesi has been cloned and differs both in sequence and organisation from its $P$. falciparum counterpart (al-Khedery et al., 1999). In addition a major gene family has been discovered in $P$. vivax called the vir genes which is also located within the sub-telomeric regions (del Portillo et al., 2001). Subsequently genes related to vir were identified in the rodent malarias $P$. chabaudi, P. yoelii, and P. berghei (Carlton and Carucci,

\begin{tabular}{|c|c|c|}
\hline Host Receptor & Cellular Target(s) & Parasite Ligand \\
\hline Thrombospondin (Roberts et al., 1985) & Endothelium & $\begin{array}{l}\text { Modified Band } 3 \text { (Eda et al., 1999) } \\
\text { PfEMP1 }\end{array}$ \\
\hline $\begin{array}{l}\text { CD36 (Barnwell et al., 1989; Ockenhouse et al., 1989b; } \\
\text { Oquendo et al., 1989) }\end{array}$ & $\begin{array}{l}\text { Endothelium, Dendritic Cells (Urban et al., } \\
\text { 2001), Uninfected Erythrocytes (Handunnetti } \\
\text { et al., 1992), Platelet-bridged Infected } \\
\text { Erythrocytes (Pain et al., 2001) }\end{array}$ & $\begin{array}{l}\text { CIDR } \alpha \\
\text { (Baruch et al., 1996; Baruch et al., 1997) }\end{array}$ \\
\hline ICAM-1 (Berendt et al., 1989) & Endothelium & $\begin{array}{l}\text { DBL } \beta C 2 \\
\text { (Baruch et al., 1996; Smith et al., 2000a) }\end{array}$ \\
\hline $\begin{array}{l}\text { VCAM-1, E-selectin (Ockenhouse et al., 1992), } \alpha_{v} \beta_{3} \text { (Siano } \\
\text { et al., 1998) }\end{array}$ & Endothelium & \\
\hline $\begin{array}{l}\text { Chondroitin-4-sulfate (CSA) (Fried \& Duffy, 1996; Rogerson } \\
\text { et al., 1995) }\end{array}$ & Placenta, Endothelium & $\begin{array}{l}\text { DBL } \gamma \\
\text { (Buffet et al., 1999; Reeder et al., 1999) }\end{array}$ \\
\hline P-Selectin (Udomsangpetch et al., 1997) & Endothelium & PfEMP1 (Senczuk et al., 2001) \\
\hline $\begin{array}{l}\text { PECAM-1 (CD31) (Newbold et al., 1997; Treutiger et al., } \\
\text { 1997) }\end{array}$ & Endothelium & $\begin{array}{l}\text { CIDR } \alpha / \text { DBL } \delta \\
\text { (Chen et al., 2000) }\end{array}$ \\
\hline $\begin{array}{l}\text { Hyaluronic acid (Beeson et al., 2000), non-immune lgG } \\
\text { (Flick et al., 2001) }\end{array}$ & Placenta & \\
\hline $\begin{array}{l}\text { CR1 (Rowe et al., 1997), HS-like GAG (Chen et al., 1998), } \\
\text { Blood Group A antigen (Carlson \& Wahlgren, 1992) }\end{array}$ & Uninfected Erythrocytes & $\begin{array}{l}\text { DBL } \alpha \\
\text { (Chen et al., 1998; Rowe et al., 1997) }\end{array}$ \\
\hline IgM (Scholander et al., 1996) & Uninfected Erythrocytes & $\begin{array}{l}\text { CIDR } \alpha \\
\text { (Chen et al., 2000) }\end{array}$ \\
\hline
\end{tabular}


2002; Janssen et al., 2002). The telomeric location of variant gene families may have functional significance as recent work in $P$. falciparum has shown that telomere clusters are formed during mitosis, facilitating intergenic transfer and thereby the generation of genetic variation (Freitas-Junior et al., 2000). The accumulating evidence that different Plasmodium species have independently evolved and developed distinct variant protein families to alter the surface antigenic profile of infected erythrocytes supports an important function for this adaptation.

\section{Adhesion to Endothelium (Cytoadherence)}

Erythrocytes infected with P. falciparum "disappear" from the circulation during their development in a process called sequestration. One of the major mechanisms associated with this event is adhesion to the endothelial cells lining small blood vessels, where the shear flow forces are sufficiently reduced to allow the relatively low avidity IE/ endothelial cell (EC) interactions to operate. A large number of endothelial receptors have been identified (see Table 1 for details) but not all of these are commonly used in patient isolates. A number of studies have attempted to correlate specific receptor usage with disease severity but these experiments are complicated by a wide range of confounders, not the least that the parasites available on admission to hospital (prior to treatment) may not accurately represent the sequestered mass.

An important and reproducible finding that has emerged from these investigations is that the host cell receptor CD36 is a major endothelial receptor for parasite cytoadherence both in terms of how frequently the receptor is utilised by different parasite isolates and the strength of binding. Indeed, most infections are characterised by parasites that bind CD36 to some extent (Newbold et al., 1997), with the important exception of parasites sequestered in the placenta (below). In addition, infected erythrocytes adhere very avidly to CD36 such that they can stably bind under conditions of flow that mimic those in microvasculature while many other parasite-receptor interactions are only able to support rolling adhesion (Cooke et al., 1994). Thus, the available evidence indicates that $P$. falciparum has made a significant investment into CD36 binding with the widespread cellular distribution of this receptor offering the parasite numerous different opportunities for host interactions. Roles for the parasite-CD36 interaction beyond sequestration are discussed below. By comparison to CD36, other receptor adhesion traits are less common or else support weaker binding. However, there is evidence that multiple receptor interactions can act cooperatively to anchor the infected erythrocyte (McCormick et al., 1997).

In terms of parasite adhesion traits that may be involved in organ-specific sequestration this has generally been more difficult to investigate mainly because tissues that malarial researchers would like to study, such as brain, are not readily accessible. However, there is some evidence from sampling circulating blood and allowing parasites to mature in vitro that infected erythrocytes binding ICAM-1 are slightly increased in patients with cerebral malaria (Newbold et al., 1997). In addition, cerebral sequestered parasites specifically co-localise to endothelium expressing ICAM-1 in post- mortem histological investigations (Turner et al., 1994). An important area of future research is to further define receptors involved in cerebral sequestration in order to understand the pathological basis of this disease.

Recently, it was reported that isolates from patients with severe malaria were more likely to bind multiple receptors (Heddini et al., 2001). Many of the receptor binding events described from severe isolates also participated in rosette formation between infected and uninfected erythrocytes (below), a property that had previously associated with severe disease. Thus, a combination of binding events acting synergistically may bring about severe disease.

\section{Adhesion to Uninfected Erythrocytes (Rosetting)}

Another form of adhesion is rosetting, the binding of two of more uninfected erythrocytes to an infected cell (Udomsangpetch et al., 1989). While not all parasite isolates form rosettes and the degree of rosette formation can vary dramatically between isolates, higher rosetting rates have generally been associated with more severe disease (Carlson et al., 1990; Rowe et al., 1995) with some exceptions (al-Yaman et al., 1995).

In a $P$. falciparum clonal lineage, rosetting was shown to be a clonally variant property of parasites that was eventually demonstrated to be mediated by specific PfEMP1 proteins (Chen et al., 1998; Rowe et al., 1997). The rosettins, now recognised as rif genes, were also initially believed to participate in rosette formation but direct evidence for this role is lacking. There are a number of receptors on the red cell surface that can participate in rosette formation including complement receptor 1 (CR1) (Rowe et al., 1997), Heparan-sulfate (Chen et al., 1998), and the ABO blood group (particularly group A) (Carlson and Wahlgren, 1992). In addition, rouleaux-forming serum proteins are also involved in rosetting (Treutiger et al., 1999). Interestingly, CR1 polymorphisms are common in Africans suggesting the possibility that they may have a protective role against severe malaria (Moulds et al., 2001).

Rosetting parasites differ in their receptor specificity. For instance, not all rosetting parasites bind CR1, parasites differ in their susceptibility to rosette disruption with heparin (Rogerson et al., 1994), and parasites can form small or large rosettes. This variability highlights a limitation of correlative studies that tend to lump multifactorial binding phenotypes together or do not account for the possibility that binding properties may exist in different adhesive contexts on different PfEMP1. Thus, it may be a simplification to assume that all rosetting or all ICAM-1 binding parasites possess the same potential for disease.

\section{Adhesion to Other Infected Erythrocytes (Autoagglutination)}

Besides binding uninfected erythrocytes, a subset of parasites form autoagglutinates with other infected erythrocytes. Autoagglutination has also been shown to be a clonally variant property (Roberts et al., 1992). Recently, it was demonstrated that autoagglutinate clumps were bridged by platelet cells (Pain et al., 2001). One of the important receptors supporting platelet-mediated 
clumping of infected erythrocytes is CD36. Since most parasites bind CD36 but do not form autoagglutinates, differences in parasite affinity or specificity for CD36 may be important for clump formation. Alternatively, there may be additional platelet-specific receptors required in combination to CD36 for autoagglutinates to form. Autoagglutination is observed in field isolates and associated with more severe disease (Roberts et al., 2000).

\section{Adhesion to Monocytes and Dendritic Cells}

Infected erythrocytes also bind other cells in the blood circulation including monocytes and dendritic cells (Ockenhouse et al., 1989a; Urban et al., 1999). Again, CD36 has been demonstrated to be an important receptor bridging these interactions (Urban et al., 2001). Infected erythrocyte adhesion to monocytes has been demonstrated to induce an oxidative burst (Ockenhouse et al., 1989a). In contrast, infected erythrocyte adhesion to dendritic cells in vitro has been shown to downmodulate their antigen-presenting activity and their capacity to stimulate T cells (Urban et al., 1999). Whether this same effect occurs during natural malaria infections in the cellular environment in which $T$ cells are activated is unknown but because dendritic cells are crucial for inducing immune responses this effect could contribute to the immunosuppression typical of malaria infection. One of the functions of CD36 is to act as a receptor in the uptake of apoptotic cells. It has been hypothesised that infected erythrocytes binding to CD36 on dendritic cells may subvert an immodulatory pathway that evolved to prevent autoimmune disease (Urban et al., 2001).

\section{Adhesion to Placenta}

The best understood system of organ-specific sequestration is the placenta due to the fact that sequestered parasites can be directly studied from this tissue after delivery. For a long time it had been recognised that women in Africa, even those with significant preexisting malaria immunity, became susceptible to malaria infection during pregnancy. Malaria during pregnancy is associated with a massive accumulation of infected erythrocytes in the placenta, which can cause severe anaemia in mothers but also appears to be responsible for the development of low-birth weight babies at increased risk of death (Brabin, 1983; Walter et al., 1982). The severity of malaria during pregnancy typically diminishes with successive pregnancies and is correlated with less sequestered parasites in the placentas of multi-gravid women and the acquisition of antibodies to placental-binding parasites (Fried et al., 1998; Staalsoe et al., 2001).

Fried and Duffy performed the seminal experiments investigating the binding properties of placentalsequestered parasites. The remarkable observation that they made was that unlike most infections, placenta sequestered parasites did not bind CD36 but rather these parasites had special affinity for chondroitin-sulfate A (CSA) (Fried and Duffy, 1996; Rogerson et al., 1995). Interestingly, CSA-adherent parasites are rare in nonpregnant individuals. The model that emerged from these studies is that the placenta enriches for parasite binding variants that do not adhere well to microvasculature but have a special affinity for the placenta. Consequently, pregnant mothers become infected with parasite binding variants to which to which they have not previously developed immunity (for review see Beeson et al. (2001), Scherf et al. (2001)).

Although CSA-containing proteoglycans are widely distributed throughout the vascular endothelium, placental CSA has a unique chemistry with an especially low sulfate content to which infected erythrocytes adhere more avidly (Achur et al., 2000; Alkhalil et al., 2000). Indeed, the placental intervillous spaces contain a weblike matrix of the low sulfate proteoglycans which might "capture" infected erythrocytes and explain the mystery of why many placental sequestered infected erythocytes are not closely associated to cells. In addition, placental syncytiotrophoblasts are also known to bind infected erythrocytes. Thrombomodulin, a CSA-containing proteoglycan expressed by syncytiotrophoblast cells, has been shown to support parasite adhesion in vitro (Gysin et al., 1997) and may be one of the sources for two cellassociated proteoglycans that were also characterised from placenta (Achur et al., 2000).

Since the first binding descriptions it has been reported that placental-sequestered parasites can also bind hyaluronic acid (Beeson et al., 2000) and nonimmune immunoglobulins (Flick et al., 2001), although there is still some controversy over whether hyaluronic acid is a receptor (Valiyaveettil et al., 2001). Current efforts are directed at defining the relative importance of these different receptors for placental sequestration and other possible undefined placental sequestration receptors. Another major avenue of research is to understand a protective immune response that develops in pregnant mothers and prevents parasite adhesion to CSA. Remarkably, the anti-adhesion antibodies are pan-reactive and recognise placental sequestered parasites from all over the world (Fried et al., 1998). This contrasts with typical anti-adhesion antibodies detected in children and adults that are typically highly strain-specific (Bull et al., 1998). The evolution of broadly protective anti-adhesion antibodies in pregnant mothers is an encouraging sign and suggests that it may be possible to develop vaccines directed at parasite-encoded, variant erythrocyte surface proteins. Understanding the molecular basis and specificity of these antibodies is an important area of research (Duffy et al., 2001).

\section{Conclusions}

This review summarises the evidence for molecules at the surface of infected erythrocytes. Our increased understanding of these proteins is an important goal because of their central importance to many essential features of the parasite biology including nutrient acquisition, establishment of chronic infection with greater opportunities for transmission, and pathogenesis. In addition to the molecules discussed there is biochemical evidence for additional surface proteins (Fernandez et al., 1999; Howard, 1988). The Malaria Genome Sequencing Effort and post-genomic approaches may provide new opportunities to identify these molecules and thereby develop new strategies to combat this disease. 


\section{References}

Achur, R.N., Valiyaveettil, M., Alkhalil, A., Ockenhouse, C.F. and Gowda, D.C., 2000. Characterization of proteoglycans of human placenta and identification of unique chondroitin sulfate proteoglycans of the intervillous spaces that mediate the adherence of Plasmodium falciparum-infected erythrocytes to the placenta. J. Biol. Chem. 275(51): 40344-40356.

Alkhalil, A., Achur, R.N., Valiyaveettil, M., Ockenhouse, C.F. and Gowda, D.C., 2000. Structural requirements for the adherence of Plasmodium falciparum-infected erythrocytes to chondroitin sulfate proteoglycans of human placenta. J. Biol. Chem. 275(51): 4035740364.

al-Khedery, B., Barnwell, J.W. and Galinski, M.R., 1999. Antigenic variation in malaria: a $3^{\prime}$ genomic alteration associated with the expression of a $P$. knowlesi variant antigen. J. Biol. Chem. Cell. 3(2): 131-141.

al-Yaman, F., Genton, B., Mokela, D., Raiko, A., Kati, S., Rogerson, S., Reeder, J. and Alpers, M. 1995. Human cerebral malaria: lack of significant association between erythrocyte rosetting and disease severity. Trans. R. Soc. Trop. Med. Hyg. 89(1): 55-58.

Barnes, D.A., Thompson, J., Triglia, T., Day, K. and Kemp, D.J., 1994. Mapping the genetic locus implicated in cytoadherence of Plasmodium falciparum to melanoma cells. Mol. Biochem. Parasitol. 66(1): 21-29.

Barnwell, J.W., Asch, A.S., Nachman, R.L., Yamaya, M., Aikawa, M. and Ingravallo, P. 1989. A human 88-kD membrane glycoprotein (CD36) functions in vitro as a receptor for a cytoadherence ligand on Plasmodium falciparum-infected erythrocytes. J. Clin. Invest. 84(3): 765-772.

Baruch, D.I., Gormely, J.A., Ma, C., Howard, R.J. and Pasloske, B.L., 1996. Plasmodium falciparum erythrocyte membrane protein 1 is a parasitized erythrocyte receptor for adherence to CD36, thrombospondin, and intercellular adhesion molecule 1. Proc. Natl. Acad. Sci. USA. 93(8): 3497-3502.

Baruch, D.I., Gormely, J.A., Ma, C., Howard, R.J. and Pasloske, B.L. 1997. Identification of a region of PfEMP1 that mediates adherence of Plasmodium falciparum infected erythrocytes to CD36: conserved function with variant sequence. Blood. 90(9): 37663775.

Baruch, D.I., Ma, X.C., Singh, H.B., Bi, X., Pasloske, B.L. and Howard, R.J. 1995. Cloning the P. falciparum gene encoding PfEMP1, a malarial variant antigen and adherence receptor on the surface of parasitized human erythrocytes. Cell. 82(1): 77-87.

Beeson, J.G., Reeder, J.C., Rogerson, S.J. and Brown, G.V., 2001. Parasite adhesion and immune evasion in placental malaria. Trends Parasitol. 17(7): 331-337.

Beeson, J.G., Rogerson, S.J., Cooke, B.M., Reeder, J.C., Chai, W., Lawson, A.M., Molyneux, M.E. and Brown, G.V. 2000. Adhesion of Plasmodium falciparuminfected erythrocytes to hyaluronic acid in placental malaria. Nat. Med. 6(1): 86-90.

Berendt, A.R., Simmons, D.L., Tansey, J., Newbold, C.I. and Marsh, K., 1989. Intercellular adhesion molecule-1 is an endothelial cell adhesion receptor for Plasmodium falciparum. Nature. 341(6237): 57-59.
Bowman, S., Lawson, D., Basham, D., Brown, D., Chillingworth, T., Churcher, C.M., Craig, A., Davies, R.M., Devlin, K., Feltwell, T., Gentles, S., Gwilliam, R., Hamlin, N., Harris, D., Holroyd, S., Hornsby, T., Horrocks, P., Jagels, K., Jassal, B., Kyes, S., McLean, J., Moule, S., Mungall, K., Murphy, L., Barrell, B.G. et al. 1999. The complete nucleotide sequence of chromosome 3 of Plasmodium falciparum. Nature. 400(6744): 532-538.

Brabin, B.J., 1983. An analysis of malaria in pregnancy in Africa. Bull World Health Organ. 61(6): 1005-1016.

Brown, K.N. and Brown, I.N., 1965. Immunity to malaria antigenic variation in chronic infections in P.knowlesi. Nature. 208: 1286-1288.

Buffet, P.A., Gamain, B., Scheidig, C., Baruch, D., Smith, J.D., Hernandez-Rivas, R., Pouvelle, B., Oishi, S., Fujii, N., Fusai, T., Parzy, D., Miller, L.H., Gysin, J. and Scherf, A. 1999. Plasmodium falciparum domain mediating adhesion to chondroitin sulfate $A$ : $A$ receptor for human placental infection. Proc. Natl. Acad. Sci. USA. 96(22): 12743-12748.

Bull, P.C., Lowe, B.S., Kortok, M., Molyneux, C.S., Newbold, C.I. and Marsh, K. 1998. Parasite antigens on the infected red cell surface are targets for naturally acquired immunity to malaria. Nat Med. 4(3): 358-360.

Bull, P.C. and Marsh, K., 2002. The role of antibodies to Plasmodium falciparum-infected-erythrocyte surface antigens in naturally acquired immunity to malaria. Trends Microbiol. 10(2): 55-58.

Carlson, J., Helmby, H., Hill, A.V., Brewster, D., Greenwood, B.M. and Wahlgren, M. 1990. Human cerebral malaria: association with erythrocyte rosetting and lack of anti-rosetting antibodies. Lancet. 336(8729): 1457-1460.

Carlson, J. and Wahlgren, M., 1992. Plasmodium falciparum erythrocyte rosetting is mediated by promiscuous lectin-like interactions. J. Exp. Med. 176(5): 1311-1317.

Carlton, J.M. and Carucci, D.J., 2002. Rodent models of malaria in the genomics era. Trends Parasitol. 18(3): 100-102.

Chaiyaroj, S.C., Coppel, R.L., Magowan, C. and Brown, G.V., 1994. A Plasmodium falciparum isolate with a chromosome 9 deletion expresses a trypsin-resistant cytoadherence molecule. Mol. Biochem. Parasitol. 67(1): 21-30.

Chen, Q., Barragan, A., Fernandez, V., Sundstrom, A., Schlichtherle, M., Sahlen, A., Carlson, J., Datta, S. and Wahlgren, M. 1998. Identification of Plasmodium falciparum erythrocyte membrane protein 1 (PfEMP1) as the rosetting ligand of the malaria parasite $P$. falciparum. J. Exp. Med. 187(1): 15-23.

Chen, Q., Heddini, A., Barragan, A., Fernandez, V., Pearce, S.F. and Wahlgren, M., 2000. The semiconserved head structure of Plasmodium falciparum erythrocyte membrane protein 1 mediates binding to multiple independent host receptors. J. Exp. Med. 192(1): 1-10.

Cheng, Q., Cloonan, N., Fischer, K., Thompson, J., Waine, G., Lanzer, M. and Saul, A. 1998. stevor and rif are Plasmodium falciparum multicopy gene families which potentially encode variant antigens. Mol. Biochem. Parasitol. 97(1-2): 161-176. 
Cooke, B.M., Berendt, A.R., Craig, A.G., MacGregor, J., Newbold, C.I. and Nash, G.B. 1994. Rolling and stationary cytoadhesion of red blood cells parasitized by Plasmodium falciparum: separate roles for ICAM-1, CD36 and thrombospondin. Br. J. Haematol. 87(1): 162-170.

Cooke, B.M., Mohandas, N. and Coppel, R.L., 2001. The malaria-infected red blood cell: structural and functional changes. Adv. Parasitol. 50: 1-86.

Crabb, B.S., Cooke, B.M., Reeder, J.C., Waller, R.F., Caruana, S.R., Davern, K.M., Wickham, M.E., Brown, G.V., Coppel, R.L. and Cowman, A.F. 1997. Targeted gene disruption shows that knobs enable malariainfected red cells to cytoadhere under physiological shear stress. Cell. 89(2): 287-296.

Craig, A. and Scherf, A. 2001. Molecules on the surface of the Plasmodium falciparum infected erythrocyte and their role in malaria pathogenesis and immune evasion. Mol. Biochem. Parasitol. 115(2): 129-143.

Crandall, I. and Sherman, I.W., 1991. Plasmodium falciparum (human malaria)-induced modifications in human erythrocyte band 3 protein. Parasitology. 102 Pt 3: 335-340.

Day, K.P., Karamalis, F., Thompson, J., Barnes, D.A., Peterson, C., Brown, H., Brown, G.V. and Kemp, D.J. 1993. Genes necessary for expression of a virulence determinant and for transmission of Plasmodium falciparum are located on a 0.3-megabase region of chromosome 9. Proc. Natl. Acad. Sci. USA. 90(17): 8292-8296.

del Portillo, H.A., Fernandez-Becerra, C., Bowman, S., Oliver, K., Preuss, M., Sanchez, C.P., Schneider, N.K., Villalobos, J.M., Rajandream, M.A., Harris, D., Pereira da Silva, L.H., Barrell, B. and Lanzer, M. 2001. A superfamily of variant genes encoded in the subtelomeric region of Plasmodium vivax. Nature. 410(6830): 839-842.

Desai, S.A., Bezrukov, S.M. and Zimmerberg, J., 2000. A voltage-dependent channel involved in nutrient uptake by red blood cells infected with the malaria parasite. Nature. 406(6799): 1001-1005.

Duffy, P.E., Craig, A.G. and Baruch, D.I., 2001. Variant proteins on the surface of malaria-infected erythrocytes--developing vaccines. Trends Parasitol. 17(8): 354-356.

Eda, S., Lawler, J. and Sherman, I.W., 1999. Plasmodium falciparum-infected erythrocyte adhesion to the type 3 repeat domain of thrombospondin- 1 is mediated by a modified band 3 protein. Mol. Biochem. Parasitol. 100(2): 195-205.

Fernandez, V., Hommel, M., Chen, Q., Hagblom, P. and Wahlgren, M., 1999. small, clonally variant antigens expressed on the surface of the Plasmodium falciparum-infected erythrocyte are encoded by the rif gene family and are the target of human immune responses. J. Exp. Med. 190(10): 1393-1404.

Flick, K., Scholander, C., Chen, Q., Fernandez, V., Pouvelle, B., Gysin, J. and Wahlgren, M. 2001. Role of nonimmune IgG bound to PfEMP1 in placental malaria. Science. 293(5537): 2098-2100.

Fowler, E.V., Peters, J.M., Gatton, M.L., Chen, N. and Cheng, Q., 2002. Genetic diversity of the DBLalpha region in Plasmodium falciparum var genes among Asia-Pacific isolates. Mol. Biochem. Parasitol. 120(1): 117-126.

Freitas-Junior, L.H., Bottius, E., Pirrit, L.A., Deitsch, K.W., Scheidig, C., Guinet, F., Nehrbass, U., Wellems, T.E. and Scherf, A. 2000. Frequent ectopic recombination of virulence factor genes in telomeric chromosome clusters of P.falciparum. Nature. 407: 1018-1022.

Fried, M. and Duffy, P.E., 1996. Adherence of Plasmodium falciparum to chondroitin sulfate $A$ in the human placenta. Science. 272(5267): 1502-1504.

Fried, M., Nosten, F., Brockman, A., Brabin, B.J. and Duffy, P.E., 1998. Maternal antibodies block malaria. Nature. 395(6705): 851-852.

Gamain, B., Miller, L.H. and Baruch, D.I., 2001. The surface variant antigens of Plasmodium falciparum contain cross-reactive epitopes. Proc. Natl. Acad. Sci. USA. 98(5): 2664-2669.

Gardiner, D.L., Holt, D.C., Thomas, E.A., Kemp, D.J. and Trenholme, K.R., 2000. Inhibition of Plasmodium falciparum clag9 gene function by antisense RNA. Mol. Biochem. Parasitol. 110(1): 33-41.

Gardner, J.P., Pinches, R.A., Roberts, D.J. and Newbold, C.I., 1996. Variant antigens and endothelial receptor adhesion in Plasmodium falciparum. Proc. Natl. Acad. Sci. USA. 93(8): 3503-3508.

Gardner, M.J., Tettelin, H., Carucci, D.J., Cummings, L.M., Aravind, L., Koonin, E.V., Shallom, S., Mason, T., Yu, K., Fujii, C., Pederson, J., Shen, K., Jing, J., Aston, C., Lai, Z., Schwartz, D.C., Pertea, M., Salzberg, S., Zhou, L., Sutton, G.G., Clayton, R., White, O., Smith, H.O., Fraser, C.M., Hoffman, S.L. et al. 1998. Chromosome 2 sequence of the human malaria parasite Plasmodium falciparum. Science. 282(5391): 1126-1132.

Gysin, J., Pouvelle, B., Le Tonqueze, M., Edelman, L. and Boffa, M.C., 1997. Chondroitin sulfate of thrombomodulin is an adhesion receptor for Plasmodium falciparum-infected erythrocytes. Mol. Biochem. Parasitol. 88(1-2): 267-271.

Handunnetti, S.M., van Schravendijk, M.R., Hasler, T., Barnwell, J.W., Greenwalt, D.E. and Howard, R.J. 1992. Involvement of CD36 on erythrocytes as a rosetting receptor for Plasmodium falciparum-infected erythrocytes. Blood. 80(8): 2097-2104.

Heddini, A., Pettersson, F., Kai, O., Shafi, J., Obiero, J., Chen, Q., Barragan, A., Wahlgren, M. and Marsh, K. 2001. Fresh isolates from children with severe Plasmodium falciparum malaria bind to multiple receptors. Infect. Immun. 69(9): 5849-5856.

Helmby, H., Cavelier, L., Pettersson, U. and Wahlgren, M., 1993. Rosetting Plasmodium falciparum-infected erythrocytes express unique strain-specific antigens on their surface. Infect Immun. 61(1): 284-288.

Holt, D.C., Bourke, P.F., Mayo, M. and Kemp, D.J., 1998. A high resolution map of chromosome 9 of Plasmodium falciparum. Mol. Biochem. Parasitol. 97(1-2): 229-233.

Holt, D.C., Gardiner, D.L., Thomas, E.A., Mayo, M., Bourke, P.F., Sutherland, C.J., Carter, R., Myers, G., Kemp, D.J. and Trenholme, K.R. 1999. The cytoadherence linked asexual gene family of Plasmodium falciparum: are there roles other than cytoadherence? Int. J. Parasitol. 29(6): 939-944. 
Hommel, M., David, P.H. and Oligino, L.D., 1983. Surface alterations of erythrocytes in Plasmodium falciparum malaria. Antigenic variation, antigenic diversity, and the role of the spleen. J. Exp. Med. 157(4): 1137-1148.

Howard, R.J., 1988. Malarial proteins at the membrane of Plasmodium falciparum-infected erythrocytes and their involvement in cytoadherence to endothelial cells. Prog. Allergy. 41: 98-147.

Howard, R.J., Barnwell, J.W. and Kao, V., 1983. Antigenic variation of Plasmodium knowlesi malaria: identification of the variant antigen on infected erythrocytes. Proc. Natl. Acad. Sci. USA. 80(13): 4129-4133.

Janssen, C.S., Barrett, M.P., Turner, C.M. and Phillips, R.S., 2002. A large gene family for putative variant antigens shared by human and rodent malaria parasites. Proc. R. Soc. Lond. B. Biol. Sci. 269(1489): 431-436.

Kaneko, O., Tsuboi, T., Ling, I.T., Howell, S., Shirano, M., Tachibana, M., Cao, Y.M., Holder, A.A. and Torii, M. 2001. The high molecular mass rhoptry protein, RhopH1, is encoded by members of the clag multigene family in Plasmodium falciparum and Plasmodium yoelii. Mol. Biochem. Parasitol. 118(2): 223-231.

Kilejian, A., Rashid, M.A., Aikawa, M., Aji, T. and Yang, Y.F., 1991. Selective association of a fragment of the knob protein with spectrin, actin and the red cell membrane. Mol. Biochem. Parasitol. 44(2): 175-181.

Kyes, S., Horrocks, P. and Newbold, C., 2001. Antigenic variation at the infected red cell surface in malaria. Annu. Rev. Microbiol. 55: 673-707.

Kyes, S., Pinches, R. and Newbold, C., 2000. A simple RNA analysis method shows var and rif multigene family expression patterns in Plasmodium falciparum. Mol. Biochem. Parasitol. 105(2): 311-315.

Kyes, S., Taylor, H., Craig, A., Marsh, K. and Newbold, C., 1997. Genomic representation of var gene sequences in Plasmodium falciparum field isolates from different geographic regions. Mol. Biochem. Parasitol. 87(2): 235-238.

Kyes, S.A., Rowe, J.A., Kriek, N. and Newbold, C.I., 1999. Rifins: a second family of clonally variant proteins expressed on the surface of red cells infected with Plasmodium falciparum. Proc. Natl. Acad. Sci. USA. 96(16): 9333-9338.

Leech, J.H., Barnwell, J.W., Miller, L.H. and Howard, R.J., 1984. Identification of a strain-specific malarial antigen exposed on the surface of Plasmodium falciparuminfected erythrocytes. J. Exp. Med. 159(6): 1567-1575.

Limpaiboon, T., Shirley, M.W., Kemp, D.J. and Saul, A., 1991. 7H8/6, a multicopy DNA probe for distinguishing isolates of Plasmodium falciparum. Mol. Biochem. Parasitol. 47(2): 197-206.

MacPherson, G.G., Warrell, M.J., White, N.J., Looareesuwan, S. and Warrell, D.A., 1985. Human cerebral malaria. A quantitative ultrastructural analysis of parasitized erythrocyte sequestration. Am. J. Pathol. 119(3): 385-401.

McCormick, C.J., Craig, A., Roberts, D., Newbold, C.I. and Berendt, A.R., 1997. Intercellular adhesion molecule-1 and CD36 synergize to mediate adherence of Plasmodium falciparum-infected erythrocytes to cultured human microvascular endothelial cells. J. Clin. Invest. 100(10): 2521-2529.
Moulds, J.M., Zimmerman, P.A., Doumbo, O.K., Kassambara, L., Sagara, I., Diallo, D.A., Atkinson, J.P., Krych-Goldberg, M., Hauhart, R.E., Hourcade, D.E., McNamara, D.T., Birmingham, D.J., Rowe, J.A., Moulds, J.J. and Miller, L.H. 2001. Molecular identification of Knops blood group polymorphisms found in long homologous region $D$ of complement receptor 1. Blood. 97(9): 2879-2885.

Newbold, C., Warn, P., Black, G., Berendt, A., Craig, A., Snow, B., Msobo, M., Peshu, N. and Marsh, K.1997. Receptor-specific adhesion and clinical disease in Plasmodium falciparum. Am. J. Trop. Med. Hyg. 57(4): 389-398.

Ockenhouse, C.F., Klotz, F.W., Tandon, N.N. and Jamieson, G.A., 1991. Sequestrin, a CD36 recognition protein on Plasmodium falciparum malaria- infected erythrocytes identified by anti-idiotype antibodies. Proc. Natl. Acad. Sci. USA. 88(8): 3175-3179.

Ockenhouse, C.F., Magowan, C. and Chulay, J.D., 1989a. Activation of monocytes and platelets by monoclonal antibodies or malaria-infected erythrocytes binding to the CD36 surface receptor in vitro. J. Clin. Invest. 84(2): 468-475.

Ockenhouse, C.F., Tandon, N.N., Magowan, C., Jamieson, G.A. and Chulay, J.D., 1989b. Identification of a platelet membrane glycoprotein as a falciparum malaria sequestration receptor. Science. 243(4897): 1469-1471.

Ockenhouse, C.F., Tegoshi, T., Maeno, Y., Benjamin, C., Ho, M., Kan, K.E., Thway, Y., Win, K., Aikawa, M. and Lobb, R.R. 1992. Human vascular endothelial cell adhesion receptors for Plasmodium falciparum-infected erythrocytes: roles for endothelial leukocyte adhesion molecule 1 and vascular cell adhesion molecule 1. J. Exp. Med. 176(4): 1183-1189.

Oquendo, P., Hundt, E., Lawler, J. and Seed, B., 1989. CD36 directly mediates cytoadherence of Plasmodium falciparum parasitized erythrocytes. Cell. 58(1): 95101.

Pain, A., Ferguson, D.J., Kai, O., Urban, B.C., Lowe, B., Marsh, K. and Roberts, D.J. 2001. Plateletmediated clumping of Plasmodium falciparum-infected erythrocytes is a common adhesive phenotype and is associated with severe malaria. Proc. Natl. Acad. Sci. USA. 98(4): 1805-1810.

Pologe, L.G. and Ravetch, J.V., 1986. A chromosomal rearrangement in a $P$. falciparum histidine-rich protein gene is associated with the knobless phenotype. Nature. 322(6078): 474-477.

Pouvelle, B., Buffet, P.A., Lepolard, C., Scherf, A. and Gysin, J., 2000. Cytoadhesion of Plasmodium falciparum ring-stage-infected erythrocytes. Nature Med. 6(11): 1264-1268.

Reeder, J.C., Cowman, A.F., Davern, K.M., Beeson, J.G., Thompson, J.K., Rogerson, S.J. and Brown, G.V. 1999. The adhesion of Plasmodium falciparum-infected erythrocytes to chondroitin sulfate $A$ is mediated by $P$. falciparum erythrocyte membrane protein 1. Proc. Natl. Acad. Sci. USA. 96(9): 5198-5202.

Roberts, D.D., Sherwood, J.A., Spitalnik, S.L., Panton, L.J., Howard, R.J., Dixit, V.M., Frazier, W.A., Miller, L.H. and Ginsburg, V.1985. Thrombospondin binds 
falciparum malaria parasitized erythrocytes and may mediate cytoadherence. Nature. 318(6041): 64-66.

Roberts, D.J., Craig, A.G., Berendt, A.R., Pinches, R., Nash, G., Marsh, K. and Newbold, C.I. 1992. Rapid switching to multiple antigenic and adhesive phenotypes in malaria. Nature. 357(6380): 689-692.

Roberts, D.J., Pain, A., Kai, O., Kortok, M. and Marsh, K., 2000. Autoagglutination of malaria-infected red blood cells and malaria severity. Lancet. 355(9213): 14271428.

Rogerson, S.J., Chaiyaroj, S.C., Ng, K., Reeder, J.C. and Brown, G.V., 1995. Chondroitin sulfate $A$ is a cell surface receptor for Plasmodium falciparum-infected erythrocytes. J. Exp. Med. 182(1): 15-20.

Rogerson, S.J., Reeder, J.C., al-Yaman, F. and Brown, G.V., 1994. Sulfated glycoconjugates as disrupters of Plasmodium falciparum erythrocyte rosettes. Am. J. Trop. Med. Hyg. 51(2): 198-203.

Rowe, A., Obeiro, J., Newbold, C.I. and Marsh, K., 1995. Plasmodium falciparum rosetting is associated with malaria severity in Kenya. Infect. Immun. 63(6): 23232326.

Rowe, J.A., Moulds, J.M., Newbold, C.I. and Miller, L.H., 1997. $P$. falciparum rosetting mediated by a parasitevariant erythrocyte membrane protein and complementreceptor 1. Nature. 388(6639): 292-295.

Scherf, A., Pouvelle, B., Buffet, P.A. and Gysin, J., 2001. Molecular mechanisms of Plasmodium falciparum placental adhesion. Cell Microbiol. 3(3): 125-131.

Scholander, C., Treutiger, C.J., Hultenby, K. and Wahlgren, M., 1996. Novel fibrillar structure confers adhesive property to malaria-infected erythrocytes. Nat. Med. 2(2): 204-208.

Senczuk, A.M., Reeder, J.C., Kosmala, M.M. and Ho, M., 2001. Plasmodium falciparum erythrocyte membrane protein 1 functions as a ligand for P-selectin. Blood. 98(10): 3132-3135.

Shirley, M.W., Biggs, B.A., Forsyth, K.P., Brown, H.J., Thompson, J.K., Brown, G.V. and Kemp, D.J. 1990. Chromosome 9 from independent clones and isolates of Plasmodium falciparum undergoes subtelomeric deletions with similar breakpoints in vitro. Mol. Biochem. Parasitol. 40(1): 137-145.

Siano, J.P., Grady, K.K., Millet, P. and Wick, T.M., 1998. Short report: Plasmodium falciparum: cytoadherence to alpha(v)beta3 on human microvascular endothelial cells. Am. J. Trop. Med. Hyg. 59(1): 77-79.

Silamut, K., Phu, N.H., Whitty, C., Turner, G.D., Louwrier, K., Mai, N.T., Simpson, J.A., Hien, T.T. and White, N.J. 1999. A quantitative analysis of the microvascular sequestration of malaria parasites in the human brain. Am. J. Pathol. 155(2): 395-410.

Smith, J.D., Chitnis, C.E., Craig, A.G., Roberts, D.J., Hudson-Taylor, D.E., Peterson, D.S., Pinches, R., Newbold, C.I. and Miller, L.H. 1995. Switches in expression of Plasmodium falciparum var genes correlate with changes in antigenic and cytoadherent phenotypes of infected erythrocytes. Cell. 82(1): 101110.

Smith, J.D., Craig, A.G., Kriek, N., Hudson-Taylor, D., Kyes, S., Fagen, T., Pinches, R., Baruch, D.I., Newbold, C.I. and Miller, L.H. 2000a. Identification of a Plasmodium falciparum intercellular adhesion molecule-1 binding domain: a parasite adhesion trait implicated in cerebral malaria. Proc. Natl. Acad. Sci. USA. 97(4): 1766-1771.

Smith, J.D., Gamain, B., Baruch, D.I. and Kyes, S., 2001. Decoding the language of var genes and Plasmodium falciparum sequestration. Trends Parasitol. 17(11): 538-545.

Smith, J.D., Subramanian, G., Gamain, B., Baruch, D.I. and Miller, L.H., 2000b. Classification of adhesive domains in the Plasmodium falciparum erythrocyte membrane protein 1 family. Mol. Biochem. Parasitol. 110: 293-310.

Staalsoe, T. et al., 2001. Acquisition and decay of antibodies to pregnancy-associated variant antigens on the surface of Plasmodium falciparum-infected erythrocytes that protect against placental parasitemia. J. Infect. Dis. 184(5): 618-626.

Su, X.Z., Heatwole, V.M., Wertheimer, S.P., Guinet, F., Herrfeldt, J.A., Peterson, D.S., Ravetch, J.A. and Wellems, T.E. 1995. The large diverse gene family var encodes proteins involved in cytoadherence and antigenic variation of Plasmodium falciparum-infected erythrocytes. Cell. 82(1): 89-100.

Trenholme, K.R., Gardiner, D.L., Holt, D.C., Thomas, E.A., Cowman, A.F. and Kemp, D.J. 2000. clag9: A cytoadherence gene in Plasmodium falciparum essential for binding of parasitized erythrocytes to CD36. Proc. Natl. Acad. Sci. USA. 97(8): 4029-4033.

Treutiger, C.J., Heddini, A., Fernandez, V., Muller, W.A. and Wahlgren, M., 1997. PECAM-1/CD31, an endothelial receptor for binding Plasmodium falciparuminfected erythrocytes. Nat. Med. 3(12): 1405-1408.

Treutiger, C.J., Scholander, C., Carlson, J., McAdam, K.P., Raynes, J.G., Falksveden, L. and Wahlgren, M. 1999. Rouleaux-forming serum proteins are involved in the rosetting of Plasmodium falciparum-infected erythrocytes. Exp. Parasitol. 93(4): 215-224.

Turner, G.D., Morrison, H., Jones, M., Davis, T.M., Looareesuwan, S., Buley, I.D., Gatter, K.C., Newbold, C.I., Pukritayakamee, S., Nagachinta, B. et al. 1994. An immunohistochemical study of the pathology of fatal malaria. Evidence for widespread endothelial activation and a potential role for intercellular adhesion molecule1 in cerebral sequestration. Am. J. Pathol. 145(5): 1057-1069.

Udeinya, I.J., Graves, P.M., Carter, R., Aikawa, M. and Miller, L.H., 1983. Plasmodium falciparum: effect of time in continuous culture on binding to human endothelial cells and amelanotic melanoma cells. Exp. Parasitol. 56(2): 207-214.

Udomsangpetch, R., Reinhardt, P.H., Schollaardt, T., Elliott, J.F., Kubes, P. and Ho, M. 1997. Promiscuity of clinical Plasmodium falciparum isolates for multiple adhesion molecules under flow conditions. J. Immunol. 158(9): 4358-4364.

Udomsangpetch, R., Wahlin, B., Carlson, J., Berzins, K., Torii, M., Aikawa, M., Perlmann, P. and Wahlgren, M. 1989. Plasmodium falciparum-infected erythrocytes form spontaneous erythrocyte rosettes. J. Exp. Med. 169(5): 1835-1840. 
Urban, B.C., Ferguson, D.J., Pain, A., Willcox, N., Plebanski, M., Austyn, J.M. and Roberts, D.J. 1999. Plasmodium falciparum-infected erythrocytes modulate the maturation of dendritic cells. Nature. 400(6739): 73-77.

Urban, B.C., Willcox, N. and Roberts, D.J., 2001. A role for CD36 in the regulation of dendritic cell function. Proc. Natl. Acad. Sci. USA. 98(15): 8750-8755.

Valiyaveettil, M., Achur, R.N., Alkhalil, A., Ockenhouse, C.F. and Gowda, D.C., 2001. Plasmodium falciparum cytoadherence to human placenta: evaluation of hyaluronic acid and chondroitin 4-sulfate for binding of infected erythrocytes. Exp. Parasitol. 99(2): 57-65.

Waller, K.L., Cooke, B.M., Nunomura, W., Mohandas, N. and Coppel, R.L., 1999. Mapping the binding domains involved in the interaction between the Plasmodium falciparum knob-associated histidine-rich protein
(KAHRP) and the cytoadherence ligand $P$. falciparum erythrocyte membrane protein 1 (PfEMP1). J. Biol. Chem. 274(34): 23808-23813.

Walter, P.R., Garin, Y. and Blot, P., 1982. Placental pathologic changes in malaria. A histologic and ultrastructural study. Am. J. Pathol. 109(3): 330-342.

Weber, J.L., 1988. Interspersed repetitive DNA from Plasmodium falciparum. Mol. Biochem. Parasitol. 29(23): 117-124.

Waters, C.T. and Janse, C.J. 2004. Malaria Parasites: Genomes and Molecular Biology (Wymondham: Caister Academic Press).

Winograd, E. and Sherman, I.W., 1989. Characterization of a modified red cell membrane protein expressed on erythrocytes infected with the human malaria parasite Plasmodium falciparum: possible role as a cytoadherent mediating protein. J. Cell. Biol. 108(1): 23-30. 


\section{Further Reading}

Caister Academic Press is a leading academic publisher of advanced texts in microbiology, molecular biology and medical research. Full details of all our publications at caister.com

- MALDI-TOF Mass Spectrometry in Microbiology Edited by: M Kostrzewa, S Schubert (2016) www.caister.com/malditof

- Aspergillus and Penicillium in the Post-genomic Era Edited by: RP Vries, IB Gelber, MR Andersen (2016) www.caister.com/aspergillus2

- The Bacteriocins: Current Knowledge and Future Prospects Edited by: RL Dorit, SM Roy, MA Riley (2016)

www.caister.com/bacteriocins

- Omics in Plant Disease Resistance Edited by: V Bhadauria (2016) www.caister.com/opd

- Acidophiles: Life in Extremely Acidic Environments Edited by: R Quatrini, DB Johnson (2016) www.caister.com/acidophiles

- Climate Change and Microbial Ecology: Current Research and Future Trend

Edited by: J Marxsen (2016)

www.caister.com/climate

- Biofilms in Bioremediation: Current Research and Emerging Technologies

Edited by: G Lear (2016)

www.caister.com/biorem

- Microalgae: Current Research and Applications Edited by: MN Tsaloglou (2016) www.caister.com/microalgae

- Gas Plasma Sterilization in Microbiology: Theory, Applications, Pitfalls and New Perspectives Edited by: H Shintani, A Sakudo (2016) www.caister.com/gasplasma

- Virus Evolution: Current Research and Future Directions Edited by: SC Weaver, M Denison, M Roossinck, et al. (2016) www.caister.com/virusevol

- Arboviruses: Molecular Biology, Evolution and Control Edited by: N Vasilakis, DJ Gubler (2016) www.caister.com/arbo

- Shigella: Molecular and Cellular Biology Edited by: WD Picking, WL Picking (2016) www.caister.com/shigella

-Aquatic Biofilms: Ecology, Water Quality and Wastewater Treatment

Edited by: AM Romaní, H Guasch, MD Balaguer (2016)

www.caister.com/aquaticbiofilms

- Alphaviruses: Current Biology

Edited by: S Mahalingam, L Herrero, B Herring (2016)

www.caister.com/alpha

- Thermophilic Microorganisms

Edited by: F Li (2015)

www.caister.com/thermophile
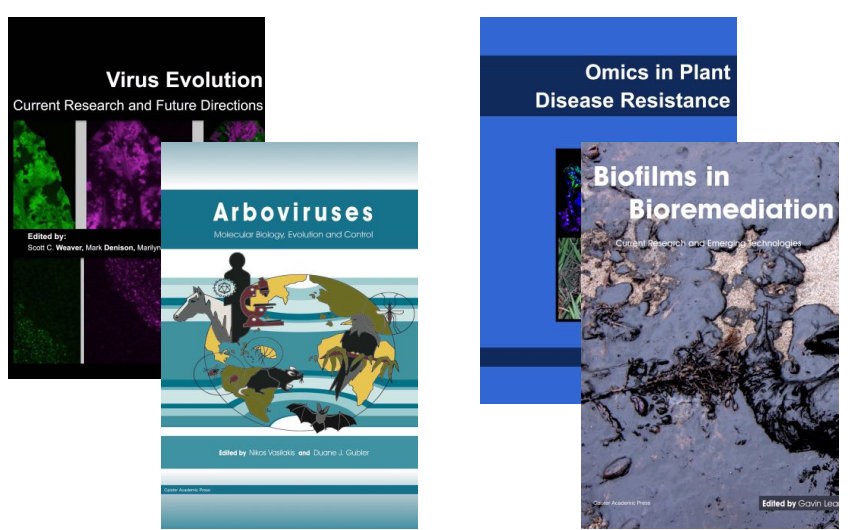
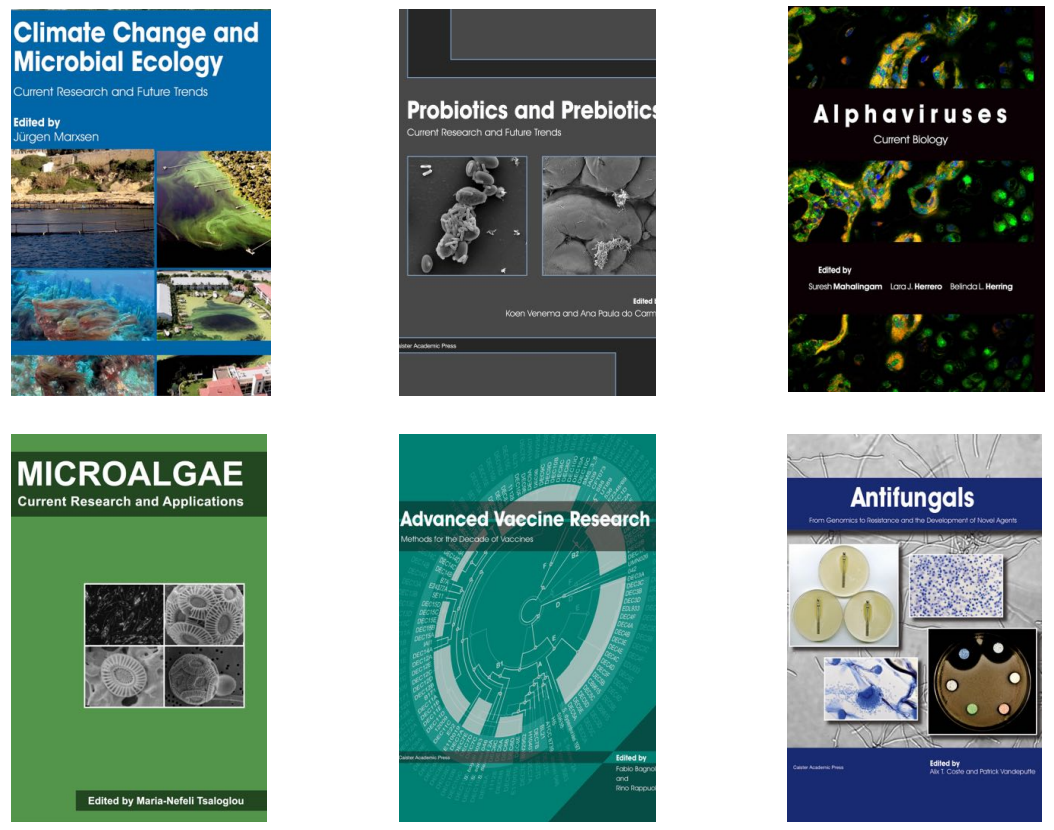

- Flow Cytometry in Microbiology: Technology and Applications Edited by: MG Wilkinson (2015) www.caister.com/flow

- Probiotics and Prebiotics: Current Research and Future Trends Edited by: K Venema, AP Carmo (2015) www.caister.com/probiotics

- Epigenetics: Current Research and Emerging Trends Edited by: BP Chadwick (2015) www.caister.com/epigenetics2015

- Corynebacterium glutamicum: From Systems Biology to Biotechnological Applications

Edited by: A Burkovski (2015)

www.caister.com/cory2

- Advanced Vaccine Research Methods for the Decade of Vaccines

Edited by: F Bagnoli, R Rappuoli (2015)

www.caister.com/vaccines

- Antifungals: From Genomics to Resistance and the Development of Novel Agents

Edited by: AT Coste, P Vandeputte (2015)

www.caister.com/antifungals

- Bacteria-Plant Interactions: Advanced Research and Future Trends Edited by: J Murillo, BA Vinatzer, RW Jackson, et al. (2015) www.caister.com/bacteria-plant

\section{- Aeromonas}

Edited by: J Graf (2015)

www.caister.com/aeromonas

- Antibiotics: Current Innovations and Future Trends

Edited by: S Sánchez, AL Demain (2015)

www.caister.com/antibiotics

- Leishmania: Current Biology and Contro Edited by: S Adak, R Datta (2015) www.caister.com/leish2

- Acanthamoeba: Biology and Pathogenesis (2nd edition) Author: NA Khan (2015)

www.caister.com/acanthamoeba2

- Microarrays: Current Technology, Innovations and Applications Edited by: Z He (2014)

www.caister.com/microarrays2

- Metagenomics of the Microbial Nitrogen Cycle: Theory, Methods and Applications

Edited by: D Marco (2014)

www.caister.com/n2 